\title{
Anticancer Potential of Aloes: Antioxidant, Antiproliferative, and Immunostimulatory Attributes
}

Authors

Affiliations
Eli Harlev ${ }^{1}$, Eviatar Nevo ${ }^{1}$, Ephraim P. Lansky ${ }^{1}$, Rivka Ofir ${ }^{2}$, Anupam Bishayee ${ }^{3}$

${ }^{1}$ Institute of Evolution and International Graduate Center of Evolution, University of Haifa, Mount Carmel, Haifa, Israel

2 Dead Sea and Arava Science Center and Ben Gurion University of the Negev, Beere Sheva, Israel

${ }^{3}$ Department of Pharmaceutical and Administrative Sciences, School of Pharmacy, American University of Health Sciences, Signal Hill, CA, USA
Key words

- Aloe vera

- Xanthorrhoeaceae

- immunobiology

- antiproliferative

anticancer

- aloe-emodin

- acemannan received February 1, 2012

revised March 11, 2012

accepted March 26, 2012

\section{Bibliography}

DOI http://dx.doi.org/

10.1055/s-0031-1298453

Published online April 19, 2012

Planta Med 2012; 78: 843-852

(C) Georg Thieme Verlag KG

Stuttgart · New York .

ISSN 0032-0943

\section{Correspondence}

\section{Eli Harlev}

Institute of Evolution and Inter-

national Graduate Center of

Evolution

University of Haifa

Mount Carmel

Haifa 31905

Israel

Phone: + 972899565713

elih@research.haifa.ac.il

\section{Abstract}

\section{$\nabla$}

Aloe is a genus of medicinal plants with a notable history of medical use. Basic research over the past couple of decades has begun to reveal the extent of Aloe's pharmaceutical potential, particularly against neoplastic disease. This review looks at Aloe, both the genus and the folk medicine, often being called informally "aloes", and delineates their chemistry and anticancer pharmacog-

\section{Introduction}

$\nabla$

Aloe is a genus of small to large, evergreen perennials, with fleshy, sword to lance-shaped leaves belonging to the Xanthorrhoeaceae family. This genus comprises about 400 species native to subSaharan Africa, the Saudi Arabian Peninsula, and many islands of the Western Indian Ocean. Although thought to grow only in hot and dry climates, Aloe plants ( $\bullet$ Fig. 1 ) actually grow in a variety of climates, including desert, grassland, coastal, or even alpine locations [1,2]. However, the majority are arid zone plants inhabiting the deserts of South Africa. These succulents, subjected to the dry areas of the tropics and subtropics, such as steppes, semi-desert, and desert, are forced to collect and store water to survive long, dry periods. Aloe plants have long been the source of important products due to their nutritional and therapeutic values, their leaf exudates being used to a great extent in traditional medicine [3].

Aloe plants exhibit anticancer activity in vitro ( Table 1) and in vivo (๑ Table 2). Their antineoplastic property is due to at least three different mechanisms based on antiproliferative, immunostimulatory, and antioxidant effects. The antiproliferative action is determined by anthracenic and anthtraquinonic molecules, such as aloeemodin, aloesin, and aloin (also called barbaloin) nosy. Structures of key compounds are provided, and their pharmacological activities reviewed. Particular attention is given to their free radical scavenging, antiproliferative, and immunostimulatory properties. This review highlights major research directions on aloes, reflecting the enormous potential of natural sources, and of the genus Aloe in particular, in preventing and treating cancer.

(๑ Fig. 2), included in the gel of the Aloe vera leaf, while the immunostimulating activity is mainly due to acemannan ( $\bullet$ Fig. 2 ), a mucopolysaccharide of Aloe vera gel, and to aloemannan included in the leaves of Aloe arborescens - both plants displaying antitumor activities in vitro through activation of immune responses [4]. Polyphenols and other reactive oxygen species (ROS) scavengers act preventively through their antioxidant effects. Aloe vera Burm. f. (also called Aloe barbadensis Miller) ( $\bullet$ Fig. 1 ) is the most known species of the Aloe genus and the most researched one. Over 4000 studies were performed on the effectiveness of Aloe vera in medical treatment, part of which addressed their role in recovery from diagnosed cancer. It grows mainly in arid and semiarid climates, although, this plant, as well as Aloe arborescens and other aloes are found also in non-arid countries like Greece, Italy, and Japan. Naturalized stands of the species occur in the southern half of the Arabian peninsula, throughout North Africa (Morocco, Mauritania, and Egypt), Sudan, and neighboring countries, and in the Canary, Cape Verde, and Madeira Islands. The species is frequently cited as being used in herbal medicine, such as in treating wounds and burns, but also diabetes and elevated blood lipids in humans [5]. These effects are attributed to compounds, such as polysaccharides, mannans, anthraquinones, and lectins, present in the Aloe leaves' gel. 

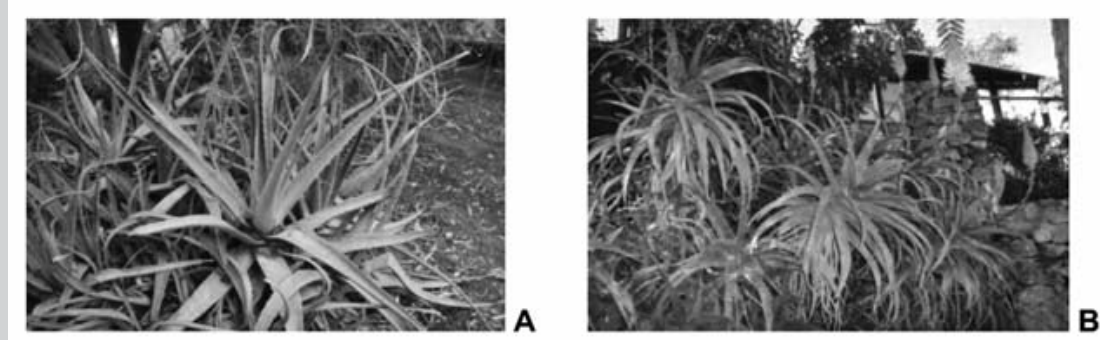

Fig. 1 The two mostly used Aloe plants in cancer research and therapy, Aloe vera $(\mathbf{A})$ and Aloe arborescens (B).

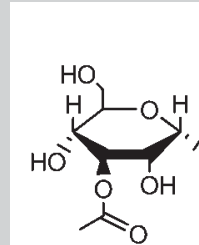<smiles>CC(=O)O[C@@H]1[C@H](CO)O[C@H](C)[C@@H](O)[C@H]1C</smiles><smiles>CC(=O)O[C@H]1[C@@H](O)[C@@H](C)OC[C@H]1O</smiles>

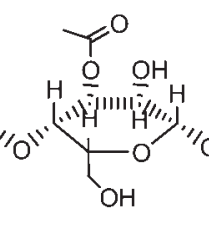<smiles>CC(=O)O[C@@H]1[C@H](O)C(O)O[C@H](C)[C@@H]1O</smiles><smiles>CC(=O)O[C@@H]1[C@H](O)CO[C@H](O)[C@@H]1O</smiles>

Fig. 2 Chemical structures of acemannan (1), aloin (2), aloe-emodin (3), and aloesin (4).<smiles>O=C1c2cc(c(O)cc2O)[C@@H]2C(=O)c3c(O)cc(CO)cc3C2c2cccc(O)c21</smiles><smiles>O=C1c2cccc(O)c2C(=O)C2C(O)=CC(CO)=CC12</smiles>

3<smiles>COCc1cc(=O)c2c(C)cc(O)c(C(OC(C)CO)OC(O)C(C)(C)CO)c2o1</smiles>

The purpose of this article is to review the work performed upto-date on the application of extracts and isolated components derived from plants of the Aloe genus in cancer research. To the best of our knowledge this attempt is a first of its kind. The article is divided into subsections, each focused on the various anticancer attributes of a major bioactive component contained in the Aloe leaf.

\section{Search Methodology}

$\nabla$

The purpose of this review has been to display before the interested reader a broad view of the research work performed upto-date on the subject. For that end, the scientific search engine "SciFinder" was found to be an extremely usefull tool, as it retrieves information from both MEDLINE and CAPLUS data bases. In most cases the whole papers were obtained and carefully gone through. In few cases only the abstract could be obtained. As the amount of work performed on the subject is not very large, any work located in the scientific literature adding new information has been incorporated into the manuscript, while concentrating on the essence and ignoring experimental details. Major key words used: cancer, anticancer, Aloe, Aloe vera, Aloe arborescence, Aloe saponaria in various combinations.

\section{Acemannan}

$\nabla$

\section{In vitro studies}

Many studies of the immunological effects of extracts from plants of Aloe have focused on the clear mesophyll gel of the Aloe vera leaf and on its major storage carbohydrate, acetylated mannan, acemannan ( $\bullet$ Fig. 2). Acemannan is the name given to the major carbohydrate fraction, a polysaccharide, or a mixture of polysaccharides, obtained from the gel of the Aloe vera leaf. Acemannan is known to have diverse biological activities, including immunomodulatory and antitumor attributes [6]. 
Table 1 In vitro anticancer effects of components included in the Aloe leaf.

\begin{tabular}{|c|c|c|c|c|c|}
\hline Compound & Plant & Cellular effects & Mechanism & Conc. & Reference \\
\hline \multirow[t]{4}{*}{ Acemannan } & Aloe vera & $\begin{array}{l}\text { Produced cell morphology changes in } \\
\text { mouse macrophage cell line (RAW } \\
264.7 \text { cells) }\end{array}$ & $\begin{array}{l}\text { Immunomodulatory } \\
\text { activities }\end{array}$ & $100 \mu \mathrm{g} / \mathrm{mL}$ & $\begin{array}{l}\text { Zhang and } \\
\text { Tizard, } 1996[4]\end{array}$ \\
\hline & Aloe vera & $\begin{array}{l}\text { Inhibited }\left[{ }^{3} \mathrm{H}\right] \mathrm{B}[\mathrm{a}] \mathrm{P} \text {-DNA adduct for- } \\
\text { mation in primary rat hepatocytes } \\
\text { treated with }\left[{ }^{3} \mathrm{H}\right] \mathrm{B}[\mathrm{a}] \mathrm{P}\end{array}$ & & $0.4-250 \mu \mathrm{g} / \mathrm{mL}$ & $\begin{array}{l}\text { Kim and Lee, } \\
1997[7]\end{array}$ \\
\hline & $\begin{array}{l}\text { Aloe saponaria } \\
\text { and Aloe vera }\end{array}$ & $\begin{array}{l}\text { Exhibited antiproliferative effect on } \\
\text { human and mouse cultures of T lym- } \\
\text { phocites }\end{array}$ & & $0.6 \mathrm{mg} / \mathrm{mL}\left(\mathrm{I} \mathrm{C}_{50}\right)$ & $\begin{array}{l}\text { Sampedro et al., } \\
2004 \text { [9] }\end{array}$ \\
\hline & Aloevera & $\begin{array}{l}\text { Induced tumor cell cytotoxicity in } \\
\text { murine peritoneal macrophage cells }\end{array}$ & $\begin{array}{l}\text { Murine macrophage stimu- } \\
\text { lation }\end{array}$ & $500 \mu \mathrm{g} / \mathrm{mL}$ & $\begin{array}{l}\text { Liu et al., } 2006 \\
\text { [12] }\end{array}$ \\
\hline \multirow[t]{2}{*}{ Aloin } & Aloevera & $\begin{array}{l}\text { Showed antiproliferative effect in He- } \\
\text { LaS3 human cervix carcinoma cells }\end{array}$ & $\uparrow$ Apoptosis & $97 \mu \mathrm{M}\left(\mathrm{IC}_{50}\right)$ & $\begin{array}{l}\text { Niciforovic et al., } \\
2007[16]\end{array}$ \\
\hline & Not specified & $\begin{array}{l}\text { Exhibited cytotoxic activity against } \\
\text { two human breast cancer cell lines } \\
\text { (MCF- } 7 \text { and SKBR-3) }\end{array}$ & $\begin{array}{l}\uparrow \text { Apoptosis, } \downarrow \text { topoisomer- } \\
\text { ase type IIA, } \downarrow \text { cyclin B1 }\end{array}$ & $\begin{array}{l}60 \mu \mathrm{g} / \mathrm{mL}(\mathrm{MCF}-7) \\
80 \text { and } 150 \mu \mathrm{g} / \mathrm{mL} \\
(\text { SKBR-3) }\end{array}$ & $\begin{array}{l}\text { Esmat et al., } 2006 \\
{[18]}\end{array}$ \\
\hline \multirow[t]{14}{*}{ Aloe-emodin } & Aloe vera & $\begin{array}{l}\text { Produced reproducible antitumor } \\
\text { effects in human } \mathrm{K} 562 \text { leukemia cell } \\
\text { line }\end{array}$ & & $\begin{array}{l}29 \mu \mathrm{M}\left(\mathrm{IC}_{50}, \mathrm{~K} 562\right) \\
10.5 \mu \mathrm{M}\left(\mathrm{IC}_{50}\right. \\
\mathrm{K} 562 / \mathrm{R})\end{array}$ & $\begin{array}{l}\text { Grimaudo et al., } \\
1997 \text { [25] }\end{array}$ \\
\hline & & $\begin{array}{l}\text { Induced cytotoxicity in human colon } \\
\text { carcinoma cell lines (DLD-1 and } \\
\text { WiDr) }\end{array}$ & $\begin{array}{l}\downarrow \text { Apoptosis, } \downarrow \text { casein kinase } \\
\text { II, } \uparrow \text { cyt. c, } \uparrow \text { caspase- } 3 \text { acti- } \\
\text { vation }\end{array}$ & $0.37 \mathrm{mM}$ & $\begin{array}{l}\text { Lin and Uen, } \\
2010[26]\end{array}$ \\
\hline & Not specified & $\begin{array}{l}\text { Reduced cytotoxicity of TNF- } \alpha \\
\text { towards L929 mouse fibrosarcoma } \\
\text { and U251 human glioma cell lines }\end{array}$ & $\begin{array}{l}\uparrow \text { Autophagy, } \downarrow \text { ERK activa- } \\
\text { tion }\end{array}$ & $5-120 \mu \mathrm{M}$ & $\begin{array}{l}\text { Harhaji et al., } \\
2007 \text { [27] }\end{array}$ \\
\hline & Aloe vera & $\begin{array}{l}\text { Displayed a long-term antiprolifera- } \\
\text { tion effect in human gastric cancer } \\
\text { MGC-803 and SGC-7901 cells }\end{array}$ & $\downarrow$ PKC, $\downarrow$ c-myc & $40 \mu \mathrm{M}$ & $\begin{array}{l}\text { Guo et al., } 2008 \\
\text { [28] }\end{array}$ \\
\hline & Not specified & $\begin{array}{l}\text { Inhibited the viability of T24 human } \\
\text { bladder cancer cells }\end{array}$ & $\begin{array}{l}\uparrow p 53, \uparrow p 21, \uparrow \text { Bax, } \uparrow \text { Fas } / \\
\text { APO- } 1, \uparrow \text { caspase-3 }\end{array}$ & $50 \mu \mathrm{M}$ & $\begin{array}{l}\text { Lin et al., } 2006 \\
\text { [29] }\end{array}$ \\
\hline & Aloe vera & $\begin{array}{l}\text { Decreased cell proliferation in trans- } \\
\text { formed glia (SVG) and human glioma } \\
\text { U-373MG cell line (U-373MG) }\end{array}$ & $\begin{array}{l}\downarrow S \text { phase progression, } \\
\downarrow \text { PKC activity }\end{array}$ & $40 \mu \mathrm{M}$ & $\begin{array}{l}\text { Acevedo-Duncan } \\
\text { et al., } 2004 \text { [24] }\end{array}$ \\
\hline & Not specified & $\begin{array}{l}\text { Differentiated surviving cells toward } \\
\text { the astrocytic lineage and exhibited } \\
\text { autophagic cell death in rat C6 glioma } \\
\text { cell line }\end{array}$ & $\begin{array}{l}\text { Formation of intracytoplas- } \\
\text { mic acidic vesicles, } \downarrow \text { ERK } 1 / 2\end{array}$ & $40 \mu \mathrm{M}$ & $\begin{array}{l}\text { Mijatovic et al., } \\
2005 \text { [30] }\end{array}$ \\
\hline & Not specified & $\begin{array}{l}\text { Caused cell death in human lung } \\
\text { squamous cell carcinoma cell line } \\
\text { (CH27) }\end{array}$ & $\begin{array}{l}\uparrow \text { caspase }-3, \uparrow \text { caspase- } 8 \\
\uparrow \text { caspase- } 9, \uparrow \text { Bax, } \uparrow \text { Fas }\end{array}$ & $50 \mu \mathrm{M}$ & $\begin{array}{l}\text { Lee et al., } 2001 \\
\text { [31] }\end{array}$ \\
\hline & Not specified & $\begin{array}{l}\text { Inhibited cell proliferation in human } \\
\text { liver cancer cell lines (HepG2 and Hep } \\
\text { 3B) }\end{array}$ & $\begin{array}{l}\uparrow \text { Apoptosis, } \uparrow \text { p } 53, \uparrow p 21 \\
\text { G1 arrest }\end{array}$ & 10 and $20 \mu \mathrm{g} / \mathrm{mL}$ & $\begin{array}{l}\text { Kuo et al., } 2002 \\
\text { [32] }\end{array}$ \\
\hline & Not specified & $\begin{array}{l}\text { Induced cytotoxicity in human lung } \\
\text { non-small cell carcinoma cell line } \\
\text { H460 }\end{array}$ & $\begin{array}{l}\uparrow \text { Apoptosis, modulation of } \\
\text { cAMP-dependent protein ki- } \\
\text { nase, PKC, Bcl-2, caspase- } 3 \text {, } \\
\text { and p38 protein expression }\end{array}$ & $40 \mu \mathrm{M}$ & $\begin{array}{l}\text { Yeh et al., } 2003 \\
\text { [33] }\end{array}$ \\
\hline & Not specified & $\begin{array}{l}\text { Inhibited growth of metastatic lesion } \\
\text { of Merkel cell carcinoma (MCC) cells }\end{array}$ & Not specified & & $\begin{array}{l}\text { Wasserman et al., } \\
2002[34]\end{array}$ \\
\hline & Not specified & $\begin{array}{l}\text { Induced cell death in human tongue } \\
\text { squamous carcinoma SCC- } 4 \text { cells }\end{array}$ & $\begin{array}{l}\uparrow \text { Apoptosis, S-phase arrest, } \\
\uparrow \text { AIF, } \uparrow \text { Endo G, } \uparrow \text { pro-cas- } \\
\text { pase- } 9, \uparrow \text { cyt. c, } \uparrow \text { Bax/Bcl2, } \\
\uparrow \text { caspase-9, } \uparrow \text { caspase-3 }\end{array}$ & $30 \mu \mathrm{M}$ & $\begin{array}{l}\text { Chiu et al., } 2009 \\
\text { [35] }\end{array}$ \\
\hline & Aloe vera & $\begin{array}{l}\text { Caused cell death in human gastric } \\
\text { carcinoma cell lines (AGS and } \\
\text { NCI-N87) }\end{array}$ & $\begin{array}{l}\uparrow \text { Apoptosis, } \uparrow \text { cyt. c, } \uparrow \text { cas- } \\
\text { pase- } 3, \downarrow \text { casein kinase, } \\
\downarrow \text { pBid }\end{array}$ & $70-190 \mu \mathrm{M}$ & $\begin{array}{l}\text { Chen et al., } 2007 \\
\text { [36] }\end{array}$ \\
\hline & & $\begin{array}{l}\text { Exhibited cytotoxicity against two } \\
\text { human colon cancer cell lines, namely } \\
\text { DLD-1 and HT2 }\end{array}$ & & $\begin{array}{l}8.94 \mu \mathrm{M}\left(\mathrm{IC}_{50}, \mathrm{DLD}-\right. \\
1) ; 10.78 \mu \mathrm{M}\left(\mathrm{IC}_{50},\right. \\
\mathrm{HT} 2)\end{array}$ & $\begin{array}{l}\text { El-Shemi et al., } \\
2010[48]\end{array}$ \\
\hline
\end{tabular}

The anticancer biological mechanism of acemannan may be exerted through pluripotent effector cells, such as macrophages, as Aloe extracts are known to induce macrophage activating activ- ity. In mouse macrophage cell line, RAW 264.7 cells, acemannan stimulated macrophage cytokine production, nitric oxide (NO) release, surface molecular expression, and cell morphology 
Table 2 In vivo anticancer effects of components included in the Aloe leaf.

\begin{tabular}{|c|c|c|c|c|c|}
\hline Compound & Plant & Biological effects & Mechanism & Dose & Reference \\
\hline \multirow[t]{3}{*}{ Acemannan } & Aloe vera & $\begin{array}{l}\text { Showed inhibitory effect on B[a]P-DNA } \\
\text { adduct formation in liver, kidney, fore- } \\
\text { stomach, and lung of male ICR mice }\end{array}$ & & $\begin{array}{l}10-50 \mathrm{mg} / \text { mouse/ } \\
\text { day }\end{array}$ & $\begin{array}{l}\text { Kim and Lee, } 1997 \\
\text { [7] }\end{array}$ \\
\hline & Aloe vera & $\begin{array}{l}\text { Exhibited macrophage-activating activ- } \\
\text { ity in ICR mice implanted with sarcoma } \\
180 \text { cells }\end{array}$ & & $1 \mathrm{mg} /$ mouse/day & Im et al., 2005 [8] \\
\hline & Aloe vera & $\begin{array}{l}\text { Caused tumor shrinkage, tumor necrosis } \\
\text { and lymphocytic infiltration in dogs }\end{array}$ & $\begin{array}{l}\text { Immunomodulatory } \\
\text { effects }\end{array}$ & & $\begin{array}{l}\text { Harris et al., } 1991 \\
\text { [14] }\end{array}$ \\
\hline $\begin{array}{l}\text { Acemannan and } \\
\text { carrisyn }\end{array}$ & Aloe vera & $\begin{array}{l}\text { Exhibited better survival of implanted } \\
\text { tumor-bearing animals }\end{array}$ & $\begin{array}{l}\text { Initiation of phagocyte } \\
\text { production, stimulation } \\
\text { of blastogenesis in thy- } \\
\text { mocytes }\end{array}$ & & $\begin{array}{l}\text { Peng et al., } 1991 \\
\text { [10] }\end{array}$ \\
\hline \multirow[t]{2}{*}{ Aloctin A } & Aloe arborescens & $\begin{array}{l}\text { Induced antitumor effects in chemically- } \\
\text { induced murine fibrosarcoma and } \\
\text { lymphocytic leukemia in mice }\end{array}$ & $\begin{array}{l}\text { Immunomodulatory } \\
\text { activities }\end{array}$ & & Kenichi, 1993 [39] \\
\hline & & $\begin{array}{l}\text { Inhibited growth of chemically-induced } \\
\text { fibrosarcoma in BALB/c mice }\end{array}$ & $\begin{array}{l}\text { Immunomodulatory } \\
\text { activity }\end{array}$ & & $\begin{array}{l}\text { Imanishi et al., } \\
1981[40]\end{array}$ \\
\hline Aloe-emodin & Aloevera & $\begin{array}{l}\text { Selectively inhibited the growth of hu- } \\
\text { man neuroectodermal tumors in mice }\end{array}$ & $\uparrow$ Apoptosis & $50 \mathrm{mg} / \mathrm{kg}$ & $\begin{array}{l}\text { Pecere et al., } 2000 \\
\text { [37] }\end{array}$ \\
\hline Aloe extract & Not specified & $\begin{array}{l}\text { Caused a decrease of } \alpha \text {-fetoprotein in } \\
\text { patients with liver cirrhosis }\end{array}$ & & $\begin{array}{l}10 \% \text { extract in } \\
\text { drinking water }\end{array}$ & Okada, 1997 [45] \\
\hline Aloe mannan & Aloe arborescens & $\begin{array}{l}\text { Showed antitumor activity against im- } \\
\text { planted sarcoma } 180 \text { in mice }\end{array}$ & & & $\begin{array}{l}\text { Yagi et al., } 1977 \\
\text { [43] }\end{array}$ \\
\hline $\begin{array}{l}\text { Aloe poly- } \\
\text { saccharides }\end{array}$ & Not specified & $\begin{array}{l}\text { Reduced the tumor weight and pro- } \\
\text { longed the survival time of tumor-bear- } \\
\text { ing mice }\end{array}$ & $\begin{array}{l}\uparrow I \mathrm{IL}-2, \uparrow \mathrm{TNF} \text {, immuno- } \\
\text { modulatory activity }\end{array}$ & & $\begin{array}{l}\text { Wang et al., } 2001 \\
\text { [13] }\end{array}$ \\
\hline $\begin{array}{l}\text { Aloesin, aloe- } \\
\text { emodin, and } \\
\text { aloin }\end{array}$ & Aloe vera & $\begin{array}{l}\text { Exhibited prolongation of the life span of } \\
\text { tumor-transplanted animals }\end{array}$ & $\begin{array}{l}\text { Modulation of antioxi- } \\
\text { dant and detoxification } \\
\text { enzymes }\end{array}$ & & $\begin{array}{l}\text { El-Shemy et al., } \\
2010[48]\end{array}$ \\
\hline $\begin{array}{l}\text { Capsules } \\
\text { containing poly- } \\
\text { saccharides }\end{array}$ & $\begin{array}{l}\text { Opuntia milpa Alta } \\
\text { and Aloe vera } L \text {. }\end{array}$ & $\begin{array}{l}\text { Inhibited the growth of tumor, and pro- } \\
\text { longed the survival of tumor-bearing } \\
\text { mice }\end{array}$ & $\downarrow \mathrm{Ca} 2+, \mathrm{Mg} 2+-$ ATPase & $0.25-1.0 \mathrm{~g} / \mathrm{kg}$ & $\begin{array}{l}\text { Gao et al., } 2005 \\
\text { [50] }\end{array}$ \\
\hline Lectin & Aloe arborescens & $\begin{array}{l}\text { Exhibited cytotoxic effects in MM102 } \\
\text { tumors in mice }\end{array}$ & T cell activation & $50 \mathrm{mg} / \mathrm{kg}$ & $\begin{array}{l}\text { Yoshimoto et al., } \\
1987 \text { [38] }\end{array}$ \\
\hline $\begin{array}{l}\text { Non-specified } \\
\text { aloe poly- } \\
\text { saccharide }\end{array}$ & $\begin{array}{l}\text { Aloe arborescens, } \\
\text { Aloe barbadensis, } \\
\text { Aloe yuan-jiangen- } \\
\text { sis, and Aloe chi- } \\
\text { nensis }\end{array}$ & $\begin{array}{l}\text { Exhibited resistance against liver cancer } \\
\text { cell proliferation }\end{array}$ & & $2.0-4.0 \mathrm{~g} / \mathrm{kg}$ & $\begin{array}{l}\text { Qui et al., } 2010 \\
\text { [11] }\end{array}$ \\
\hline Not specified & $\begin{array}{l}\text { Aloe arborescens } \\
\text { and Aloe vera }\end{array}$ & $\begin{array}{l}\text { Inhibited the growth of } \mathrm{S} 180 \text { tumor and } \\
\text { prolonged the survival of } \mathrm{H} 22 \text { tumor- } \\
\text { bearing mice }\end{array}$ & & & $\begin{array}{l}\text { Su et al., } 2006 \\
{[46]}\end{array}$ \\
\hline Not specified & $\begin{array}{l}\text { Aloe arborescens } \\
\text { and Aloe vera }\end{array}$ & $\begin{array}{l}\text { Prolonged life span of ICR mouse with } \\
\text { sarcoma } 180 \text { tumor }\end{array}$ & & $\begin{array}{l}10 \text { and } 50 \mathrm{mg} / \mathrm{kg} / \\
\text { day (Aloe vera); } \\
10 \text { and } 100 \mathrm{mg} / \mathrm{kg} / \\
\text { day (Aloe arbores- } \\
\text { cens) }\end{array}$ & $\begin{array}{l}\text { Jeong et al., } 1994 \\
\text { [47] }\end{array}$ \\
\hline $\begin{array}{l}\text { Whole leaf } \\
\text { powder }\end{array}$ & Aloe arborescens & $\begin{array}{l}\text { Prevented BOP-induced pancreatic neo- } \\
\text { plasia in female Syrian hamsters }\end{array}$ & $\downarrow$ DNA adduct formation & $1-5 \%$ in diet & $\begin{array}{l}\text { Furukawa et al., } \\
2002[44]\end{array}$ \\
\hline
\end{tabular}

changes [4]. The production of the cytokine interleukin 6 (IL-6) and tumor necrosis factor- $\alpha$ (TNF- $\alpha$ ) was acemannan dose-dependent, and NO production, cell morphology changes, and surface antigen expression were increased in response to stimulation by a mixture of acemannan and interferon- $\gamma$ (IFN- $\gamma$ ).

\section{In vivo studies}

The major goal of cancer chemoprevention is to reduce the incidence of human cancer, either by inhibiting the process of carcinogenesis or by preventing high levels of carcinogen exposure. The antigenotoxic and chemopreventive effect of acemannan on benzo[a]-pyrene (B[a]P)-DNA adducts was investigated in vitro and in vivo [7]. Acemannan showed time-course and dose-de- pendent inhibition of $\left[{ }^{3} \mathrm{H}\right] \mathrm{B}[\mathrm{a}] \mathrm{P}-\mathrm{DNA}$ adduct formation in primary rat hepatocytes treated with $\left[{ }^{3} \mathrm{H}\right] \mathrm{B}[\mathrm{a}] \mathrm{P}$. The polysaccharide fraction also inhibited cellular uptake of [3H]B[a]P in a dose-dependent manner. In this animal model, BPDE-I-DNA adduct formation was significantly inhibited in various organs, such as the liver, kidney, forestomach, and lung. These results suggest that the inhibitory effect of the polysaccharide fraction derived from Aloe barbadensis on BPDE-I-DNA adduct formation might have a chemopreventive effect by inhibition of $\mathrm{B}[\mathrm{a}] \mathrm{P}$ absorption.

A study examined the molecular size-immunomodulatory activity relationship of modified Aloe polysaccharide acemannan (MAP) [8]. Polysaccharides between 5 and 400 KDa exhibited the most potent macrophage-activating activity as determined 
by increased cytokine production, NO release, expression of surface molecules, and phagocytic activity. In accordance with the in vitro activity, polysaccharides also exhibited the most potent antitumor activity in vivo.

Aloe saponaria (Ait.) Haw., also known as soap aloe, African aloe, or zebra aloe, is a popular landscape plant in arid regions worldwide. It is native to eastern South Africa, Botswana, and Zimbabwe. The antiproliferative effects of the polysaccharide mannan from Aloe saponaria were evaluated using normal murine cells (SpMC) and human cells (PBMC), as well as several tumor cell lines [9]. Mannan inhibited proliferation in both normal and tumor cells, and affected the expression of CD3+SpMC, indicating that it inhibits mainly a $\mathrm{T}$ lymphocyte proliferative response. On the C1498 cell line, mannan reduced CD3 expression and abolished the CD25 expression, indicating that mannan has a dual beneficial effect when applied to normal and tumor cells (inhibiting the activation of cancer cells, and improving that of normal ones).

An extract from the parenchyma of Aloe barbadensis Miller (Aloe vera), containing long chain poly-dispersed beta $(1,4)$-linked mannan polymers with random O-acetyl groups (acemannan and carrisyn), initiated phagocyte production of monokines supporting antibody-dependent cellular cytotoxicity, and stimulated blastogenesis in thymocytes [10]. Approximately $40 \%$ of animals treated with acemannan at the time of tumor cell implantation survived. Tumors in acemannan-treated animals exhibited vascular congestion, edema, polymorphonuclear leukocyte infiltration, and central necrosing foci with hemorrhage and peripheral fibrosis. The data indicate that in vivo treatment of peritoneal macrophages stimulates the macrophage production of monokines, including IL- 1 and TNF- $\alpha$. The data further indicate that sarcomas in animals treated i. p. with acemannan at the time of tumor cell implantation were infiltrated by immune system cells, became necrotic and regressed. The combined data suggest that acemannan-stimulated synthesis of monokines resulted in the initiation of immune attack, necrosis, and regression of implanted sarcomas in mice.

A recent report deals with the use of Aloe polysaccharide extracted from Aloe arborescens, Aloe barbadensis (Aloe vera), Aloe yuan-jiangensis, Aloe chinensis, etc., in resisting liver cancer cell proliferation [11]. The Aloe polysaccharide inhibits tumor cell proliferation and growth, and is used for preparing antitumor medicines for treating liver cancer. The Aloe polysaccharide, combined with chemotherapeutic agents, such as cisplatin (DDP) and 5 -fluorouracil (5-FU), enhances the therapeutic effect and reduces adverse side effects. It can be made into a tablet, powder, capsule, granule, suspension, syrup, oral liquid, emulsion, nanoparticle, liposome, ointment, patch, and injection.

The stimulatory activity of PAC-I (acemannan polysaccharide) on murine peritoneal macrophages was reported [12]. The polysaccharide, when injected into mice, enhanced the migration of macrophages to the peritoneal cavity. Peritoneal macrophage, when treated by PAC-I in vitro, had increased expression of MHC-II and FcrR, and enhanced endocytosis, phagocytosis, NO production, TNF- $\alpha$ secretion, and tumor cell cytotoxicity. The administration of PAC-I into allogeneic ICR mice stimulated systemic TNF- $\alpha$ production in a dose-dependent manner, and prolonged the survival of tumor-bearing mice. PAC-I is, thus, a potent stimulator of murine macrophage, and the in vitro observed tumoricidal properties of activated macrophage might account for its in vivo antitumor properties, indicating possible therapeutic implications in tumor immunotherapy.
The mechanism of the antitumor activity of Aloe polysaccharides was explored [13]. Aloe polysaccharide was administered i.p. or i.v. to sarcoma 180 (S180) bearing mice or hepatoma 22 (H22)bearing mice, solely or combined with cyclophosphamide (CTX), FU, and adrenomedullin (ADM), respectively. For H22-bearing mice, the survival rate was observed or the IL- 2 and TNF- $\alpha$ content in serum tested. It was found that Aloe polysaccharide reduced the tumor weight of S180-bearing mice and prolonged the survival time of H22-bearing mice. Aloe polysaccharide improves the antitumor effects of CTX, ADM, and FU, and lessens the chemotherapy side effects. It improves the levels of IL-2 and TNF- $\alpha$ in the serum of mice bearing S180 or H22. Thus, Aloe polysaccharide acts as an antitumor, enhances the antitumor activity of chemotherapeutic drugs and lessens their side effects. These effects possibly relate to inducing IL-2, and TNF- $\alpha$ production as well as to improved immune system function.

\section{Clinical studies}

Forty-three dogs and cats with spontaneous tumors were treated with the immunostimulating polysaccharide acemannan derived from Aloe vera by intraperitoneal (i. p.) and intralesional routes of administration. Tumors from 26 of these animals showed histopathological evidence of immunological attack as shown by marked necrosis or lymphocytic infiltration. Thirteen showed moderate to marked tumor necrosis or liquefaction. Twenty-one demonstrated lymphoid infiltration, and seven demonstrated encapsulation. Twelve animals indicated obvious improvement as assessed by tumor shrinkage, tumor necrosis, or prolonged survival [14].

Recent advances in tumor immunobiology suggest the possibility of natural cancer therapy. Cytokines, such as IL-2, or neurohormones, such as the pineal indole melatonin (MLT), were found to activate anticancer immunity. Clinical studies were performed to evaluate whether the concomitant administration of Aloe may enhance the therapeutic results of MLT in patients with advanced solid tumors for whom no effective standard anticancer therapies are available [5]. The study included 50 patients suffering from lung cancer, gastrointestinal tract tumors, breast cancer, or brain glioblastoma, who were treated with MLT alone, or MLT plus Aloe vera tincture. This preliminary work suggested that natural cancer therapy with MLT plus Aloe vera extracts may produce therapeutic benefits, at least in terms of stabilization of disease and survival, in patients with advanced solid tumors for whom no other standard effective therapy is available.

\section{Aloin \\ $\nabla$}

\section{In vitro studies}

Aloin [10-glucopyranosyl-1,8-dihydroxy-3-hydroxymethyl-9 (10H)-anthracenone, O Fig. 2] is an anthraquinone glycoside, a natural bioactive compound present in Aloe vera and in many other plants of the Aloe genus. It is related to aloe-emodin which lacks a sugar group but shares aloin's biological properties. Although known to have an anticancer effect, aloin has not been used in current drug research. It has been suggested that optimization of the lead structure could enhance the utility of this compound. Hence, aloin was modified using natural amino acids to produce Schiff's base, a potential pharmacophore, and its corresponding aglycons. The synthetic glycoside derivatives exhibited significant enhancement of their antioxidant efficacy (DPPH radical scavenging) and cytotoxic activities compared to those of the 
parent compound, aloin, showing promise for application in cancer treatment [15].

The antiproliferative and cytotoxic potential of the natural anthracycline aloin from Aloe vera was tested on human uterine carcinoma HeLaS3 cells [16]. Aloin showed a pronounced antiproliferative effect at physiological concentration, caused cell cycle arrest in the S phase, and markedly increased HeLaS3 cell apoptosis, indicating that aloin, due to its less undesirable side effects and anti-metastatic potential, may be the agent of choice on which clinical protocols for the treatment of human cervical carcinoma should rely in the future.

Naturally occurring phytoanthracycline aloin was used to radiosensitize HeLaS3 cells. The results indicated that the cytotoxic adjuvant effect of aloin was synergistic with gamma ionizing radiation at all concentrations, and comparable to the cytotoxicity of 5-10 Gy ionizing radiation alone [17]. Radiosensitization of HeLaS3 cells was achieved by $60 \mu \mathrm{M}$ aloin, which reduced the $\mathrm{IC}_{50}$ dose of ionizing radiation. Ionizing radiation and aloin alone, or in combination, perturbed the HeLaS3 cell cycle, and increased the percentage of cells in the DNA synthesis (S) phase of the cell cycle. While either agent applied alone caused programmed cell death by apoptosis, the simultaneous cell damage by both agents through the altered redox balance compromised cell capacity to conduct this program, and led to synergic cytotoxic cell death by necrosis.

The cytotoxic activity of aloin from the Aloe plant against two human breast cancer cell lines, without (MCF-7) and with (SKBR-3) erbB-2-topolla coamplification, was reported [18]. MCF-7 cell line was more sensitive to aloin than SKBR-3, as demonstrated by the MTT and clonogenic assays. The effect of aloin is likely multifactorial, depending on dose level, and tumor phenotype. Aloin at higher concentrations reduced the proportion of cells undergoing mitosis by induction of apoptosis, inhibited topoisomerase type IIA expression, and downregulated cyclin B1 protein expression in the MCF-7 cell line, whereas erbB-2 protein expression was not affected. Topoisomerase type IIA expression was mildly downregulated in the SKBR-3 cell line at higher concentrations only.

\section{Aloe-emodin}

$\nabla$

Aloe-emodin [1,8-dihydroy-3-[hydroxymethyl]-anthraquione, - Fig. 2] is contained in Aloe vera leaf gel. Aloe-emodin has laxative [19], antifungal [20], anitibacterial [21], hepatoprotective [22], antiviral [23], and antitumor activities [24]. The following section describes in vitro, in vivo, and clinical anticancer studies of aloe-emodin.

\section{In vitro studies}

The effects of five compounds purified from Aloe vera on the human K562 leukemia cell line, and its multidrug-resistant (MDR) variant, K562/R, were investigated [25]. The aglycon aloe-emodin produced reproducible antitumor effects which were more pronounced in the MDR, P-glycoprotein overexpressing cell line than in the parent cells. Aloe-emodin caused cytostasis and accumulation of the cells in the S and G2-M phases of the cell cycle, and thereafter massive cell death.

The anticancer effect of aloe-emodin was tested on two human colon carcinoma cell lines, DLD-1 and WiDr [26]. It induced cell death in a dose-dependent and time-dependent manner. Notably, the WiDr cells were more sensitive to aloe-emodin than the
DLD-1 cells. Aloe-emodin affected the release of apoptosis-inducing factor and cytochrome $c$ (cyt. $c$ ) from mitochondria, followed by activation of caspase-3, leading to DNA fragmentation, nuclear shrinkage, and apoptosis. Exposing colon carcinoma cells to aloeemodin suppressed the casein kinase II activity in a time-dependent manner, and was accompanied by a reduced phosphorylation of Bid, a downstream substrate of casein kinase II, and a proapoptotic molecule. These findings indicate that the inhibition of casein kinase II activity, the release of apoptosis-inducing factor and cyt. $c$, and the caspase- 3 activation, are involved in aloeemodin-mediated apoptosis in colon carcinoma cells.

The capacity of aloe-emodin to reduce the cytotoxicity of the proinflammatory cytokine TNF- $\alpha$ towards L929 mouse fibrosarcoma and U251 human glioma cell lines was demonstrated [27]. Aloe-emodin inhibited both TNF- $\alpha$-induced cell necrosis and apoptosis, but it did not reduce cell death induced by UV radiation or hydrogen peroxide. Aloe-emodin inhibited both basal and TNF- $\alpha$ triggered activation of extracellular signal-regulated kinase (ERK), and a selective blockade of ERK activation mimicked the cytoprotective action of the drug. The combination of aloe-emodin and TNF- $\alpha$ caused an intracellular appearance of acidified autophagic vesicles, and the inhibition of autophagy with bafilomycin or 3-methyladenine efficiently blocked the cytoprotective action of aloe-emodin. These data indicate that aloe-emodin could prevent TNF- $\alpha$-triggered cell death through mechanisms involving induction of autophagy, and blockade of ERK activation.

The relatively unknown mechanism of the anticancer effect of aloe-emodin was investigated [28]. Crystal violet assay showed that it had a long-term antiproliferation effect on human gastric cancer MGC-803 and SGC-7901 cells. Scratch wound-healing motility assays indicated its anti-migration effect. Aloe-emodin arrested SGC-7901 cells at the G2/M phase. More importantly, it inhibited the expressions of protein kinase C (PKC) and c-myc, indicating that the anticancer effect of aloe-emodin on gastric cancer cells involves suppression of c-myc expression.

The anticancer effect of aloe-emodin on the T24 human bladder cancer cell line was investigated by studying apoptosis regulation [29]. It was found that it inhibited cell viability and induced G2/M arrest and apoptosis in T24 cells. Aloe-emodin increased the levels of Wee 1 and cdc25c. It induced p53 expression, and was accompanied by the induction of p21 and caspase-3 activation, associated with apoptosis. In addition, aloe-emodin was associated with a marked increase in Fas/APO1 receptor and Bax expression, but inhibited Bcl-2 expression. These results indicate that the induction of apoptosis in T24 cells by aloe-emodin is mediated through the activation of p53, p21, Fas/APO-1, Bax, and caspase-3. Aloe-emodin regulation of the cell cycle, cell proliferation, and PKC during glioma growth and development was explored [24]. The results revealed that aloe-emodin delayed the number of cells entering and exiting the DNA synthesis (S) phase in both SVG and U-373MG cells, indicating that aloe-emodin may inhibit $S$ phase progression. Assessment of cell viability demonstrated that SVG and U-373MG glioma cells were highly sensitive to aloe-emodin. A PKC activity assay was quantified to establish the role of PKC in aloe-emodin's mode of action. Exposure of SVG and U-373MG glioma cells to aloe-emodin suppressed PKC activity and reduced the protein content of most of the PKC isozymes. These results indicate that cancer growth inhibition by aloe-emodin is due to apoptosis, and support the hypothesis that aloe-emodin represents a novel antitumor chemotherapeutic drug.

The effect of aloe-emodin on the rat $\mathrm{C} 6$ glioma cell line was investigated [30]. In addition to cell cycle block and caspase-depen- 
dent apoptosis, aloe-emodin led to the formation of intracytoplasmic acidic vesicles, indicative of autophagic cell death. Moreover, differentiation of surviving cells toward the astrocytic lineage was confirmed by typical morphological changes, and increased expression of glial fibrillary acidic protein (GFAP). Aloeemodin did not affect the activation of p38 MAPK, Jun-N-terminal kinase, or transcription factor nuclear factor (NF- $k B$ ), but markedly inhibited the activation of ERK1/2 in C6 cells. A selective inhibitor of ERK activation, PD98059, mimicked the effects of aloe-emodin on glioma cell morphology and GFAP expression, but failed to induce either apoptosis or autophagy. Taken together, these results indicate that the anti-glioma action of aloe-emodin involves ERK-independent induction of both apoptosis and autophagy, as well as ERK inhibition-mediated differentiation of glioma cells.

The effects and mechanisms of aloe-emodin-induced cell death in the human lung squamous cell carcinoma cell line $\mathrm{CH} 27$ was investigated [31]. Aloe-emodin-induced $\mathrm{CH} 27$ cell apoptosis was confirmed by DNA fragmentation (DNA ladders and sub-G1 formation). Aloe-emodin-induced apoptosis of $\mathrm{CH} 27$ cells involved modulation of the expression of Bcl-2 family proteins, such as BclXL, Bag-1, and Bak, and was associated with the translocation of Bak and Bax from cytosolic to particulate fractions. Aloe-emodin-treated $\mathrm{CH} 27$ cells had an increased relative abundance of cyt. $c$ in the cytosolic fraction. These results demonstrated that the activation of caspase- 3 , caspase- 8 , and caspase- 9 is an important determinant of apoptotic death induced by aloe-emodin, suggesting that aloe-emodin induces $\mathrm{CH} 27$ cell death by the Bax and Fas death pathways.

The anticancer effect of aloe-emodin was studied in two human liver cancer cell lines; human hepatocellular carcinoma HepG2 and Hер3в [32]. Aloe-emodin inhibited cell proliferation and induced apoptosis in both cell lines, but with different antiproliferative mechanisms. In HepG2 cells, it induced p53 expression, accompanied by an induction of p21 expression that was associated with cell cycle arrest in G1. In addition, it caused a marked increase in Fas/APO1 receptor and Bax expression. In contrast, in the p53-deficient Hep3B cells, the inhibition of cell proliferation by aloe-emodin was mediated through a p21-dependent mechanism that did not cause cell cycle arrest or increase of the Fas/ APO1 receptor, but rather promoted apoptosis by enhancing expression of Bax. The above results indicate aloe-emodin's potential in liver cancer prevention.

A study investigated the effects and mechanisms of aloe-emodininduced cell death in the human lung non-small cell carcinoma cell line $\mathrm{H} 460$ [33]. Aloe-emodin-induced apoptosis of $\mathrm{H} 460$ cells involves modulation of cAMP-dependent protein kinase, PKC, Bcl-2, caspase-3, and p38 protein expression. The relationship of various signals involved in cell death, such as cAMP-dependent protein kinase, $\mathrm{PKC}, \mathrm{Bcl}-2$, caspase-3, and p38, was investigated in the regulation of apoptotic cell death of aloe-emodin. It was demonstrated that the expression of p38 is an important determinant of apoptotic death induced by aloe-emodin.

A free-floating cell line was established from a metastatic lesion of a Merkel cell carcinoma (MCC) patient. Aloe-emodin significantly inhibited the growth of the MCC cells, indicating that it is a potential agent for treating MCC [34].

An investigation was made of the anticancer effect of aloe-emodin on human tongue squamous carcinoma SCC-4 cells [35]. The results indicated that it induced cell death through S-phase arrest and apoptosis in a dose-dependent and time-dependent manner. Treatment with $30 \mu \mathrm{M}$ of aloe-emodin led to S-phase arrest through promoted p53, p21, and p27, but inhibited cyclin A, E, thymidylate synthase, and Cdc25A levels. Aloe-emodin promoted the release of apoptosis-inducing factor (AIF), endonuclease $\mathrm{G}$ (Endo G), pro-caspase-9, and cyt. $c$ from the mitochondria via a loss of the mitochondrial membrane potential, which was associated with an increase in the ratio of $\mathrm{Bax} / \mathrm{Bcl} 2$ and activation of caspase-9 and -3. Aloe-emodin thus induced apoptosis in the SCC-4 cells through the Fas/death-receptor, mitochondria and caspase cascade. The above demonstrates its potential as a novel chemotherapeutic drug for the treatment of human tongue squamous cancer.

A preclinical study investigated the anticancer effect of aloeemodin on two distinct human gastric carcinoma cell lines, AGS and NCI-N87 [36]. It demonstrated that aloe-emodin induces cell death in a dose-dependent and time-dependent manner. Aloeemodin caused the release of apoptosis-inducing factor and cyt. $c$ from mitochondria, followed by the activation of caspase-3, leading to nuclear shrinkage and apoptosis. In addition, exposure to aloe-emodin suppressed the casein kinase II activity in a timedependent manner, and was accompanied by a reduced phosphorylation of Bid, a downstream substrate of casein kinase II, and a proapoptotic molecule. This preclinical study suggests that aloe-emodin represents a suitable and novel chemotherapeutic drug candidate for the treatment of human gastric carcinoma.

\section{In vivo studies}

Aloe-emodin has a specific in vitro and in vivo anti-neuroectodermal tumor activity. It was found that the growth of human neuroectodermal tumors is inhibited in mice with severe combined immunodeficiency without any appreciable toxic effects on the animals, but it does not inhibit the proliferation of normal fibroblasts, or that of hematopoietic progenitor cells [37]. The cytotoxicity mechanism consists of the induction of apoptosis, whereas the selectivity against neuroectodermal tumor cells is founded on a specific energy-dependent pathway of drug incorporation.

\section{Lectins \\ $\nabla$}

Lectins are sugar-binding proteins present in the leaves of Aloe plants, highly specific for their sugar moieties. They play a role in biological recognition phenomena involving cells and proteins, and have many immunological activities.

\section{In vivo study}

The possibility that a plant lectin acting as a carrier protein could specifically activate $T$ cells, resulting in the augmentation of antitumor immunity was investigated [38]. ATF1011, a non-mitogenic lectin purified from the leaves of Aloe arborescens Mill, is known to bind equally to normal and tumor cells. It was found that ATF1011 binding on the MM102 tumor cell surfaces augmented anti-trinitrophenyl (TNP) antibody production of murine splenocytes when the mice were primarily immunized with TNPconjugated MM102 tumor cells. The alloreactive cytotoxic T cell response was also augmented by allostimulatory cells binding ATF1011 on the cell surfaces. These augmented responses are suggested to be mediated by the activation of helper $\mathrm{T}$ cells recognizing ATF1011 as a carrier protein. Killer T cells were induced against the ATF1011 antigen in the H-2-restricted manner, using syngeneic stimulator cells bearing ATF1011 on the cell surfaces. When this lectin was administered intralesionally into the tu- 
mors, induction of cytotoxic effector cells was demonstrated. Thus, intralesionally administered ATF1011 derived from Aloe arborescens Mill binds to the tumor cell membrane and activates $\mathrm{T}$ cells specific for this carrier lectin in situ, which results in the augmented induction of systemic antitumor immunity.

\section{Aloctin A}

$\nabla$

Aloctin A (also referred to as "Alo A") is a highly purified glycoprotein from the leaves of Aloe arborescens, exhibiting various biological activities, such as mitogenic activity for T lymphocytes, binding reactivity for human a2-macroglobulin, and activation of component 3 of the complement system via the alternative pathway 1.

\section{In vivo studies}

The antitumor activity of aloctin A was described, using methylcholanthrene-induced murinefibrosarcoma (Meth A)2, and lymphocytic leukemia (P388) in syngeneic mouse systems [39].

Aloctin A [78244-78-7] isolated from Aloe arborescens inhibited the growth of a syngeneic transplantable methylcholanthreneinduced fibrosarcoma in mice [40]. The inhibitory mechanism has been suggested to be host-mediated, and not due to a direct toxic effect on the tumor cell.

\section{Aloe Extracts and Miscellaneous Compounds} $\nabla$

In vitro study

An extract of Aloe vera (Aloe barbadensis Miller) was examined for its cellular toxicity on HepG2 cells [41]. Treatment with the extract resulted in DNA fragmentation, but not lactate dehydrogenase (LDH) release, suggested apoptosis instead of necrosis. The extract-induced cytotoxicity was mediated by a decrease in ATP levels. Inactivation of caspase-3/7 suggests the possibility of caspase-independent apoptosis. Taken together, the results show that Aloe vera extracts induce HepG2 apoptosis by ATP depletionrelated impairment of mitochondria, which is caspase-independent.

\section{In vivo studies}

Aloe arborescens Miller, known also as Krantz aloe, is the most popular source for herbal medicine, used in the treatment of various acute or chronic diseases. This plant originates from the arid zones of South Africa, and is mostly native to the south-eastern coast of the African continent. Extracts from the leaves of Aloe arborescens exhibited significant wound healing, antibacterial, antiulcer, anti-inflammatory, anticarcinogenic, hypoglycemic, and also alopoeic activity. The leaf sap has been reported to relieve X-ray burns [42]. The hot water extract of the fresh leaves of Aloe arborescens contained aloemannan, which showed activity against implanted sarcoma 180 in mice [43].

The modification effects of freeze-dried Aloe arborescens whole leaf powder during the initiation phase of carcinogenesis were investigated in hamsters treated with $\mathrm{N}$-nitroso-bis(2-oxopropyl) amine (BOP) [44]. Incidences of pancreatic adenocarcinomas, atypical hyperplasias, or total atypical hyperplasias plus adenocarcinomas were significantly decreased with $\mathrm{BOP}+5 \%$ Aloe arborescens, and that of adenocarcinomas were also significantly reduced in the $\mathrm{BOP}+1 \%$ Aloe as compared to the BOP alone group. Multiplicities of pancreatic adenocarcinomas, atypical hyperpla- sias, or total lesions, were also significantly lower in the BOP $+5 \%$ Aloe group than with the BOP alone. Quantitative data for neoplastic lesions in the lung, liver, gall bladder, kidney, and urinary bladder of hamsters were not significantly different among the three groups. The results indicated that Aloe arborescens prevents BOP-induced pancreatic neoplasia in hamsters in relation to decreased DNA adduct formation in the target tissue.

The oral administration of water-soluble ingredients of Aloe arborescens extract to patients with liver cirrhosis resulted in a marked decrease of $\alpha$-fetoprotein, which is one of the markers of hepatocarcinogenesis. This study was undertaken for the purpose of investigating the effect of Aloe arborescens extract on hepatocarcinogenesis, demonstrating that it may be useful in the chemoprevention for hepatocarcinoma due to its inhibitory effect of both hepatocarcinogenesis and cell growth [45].

The tumor-inhibition effects of various kinds of Aloe were studied on sarcoma 180 tumor bearing mice, and on the life time of H22tumor-bearing mice. Efficacy enhancing and toxicity reducing of Aloe arborescens Miller on 5-fluorouracil (5-FU) were observed. It was found that different kinds of aloes can inhibit S180 tumor, and prolong the life time of H22-bearing mice [46].

Anticancer effects of two plants of the Aloe genus were determined on sarcoma 180 in ICR mouse or human cancer cells [47]. It was found that the administration of extracts of either Aloe vera or Aloe arborescens prolonged the life span of ICR mouse.

The potential anticancer properties and modulatory effect of selected Aloe vera active compounds on antioxidant enzyme activities were tested [48]. Thus, three anthraquinones, aloesin, aloeemodin, and aloin (also called barbaloin), were extracted from Aloe vera leaves. These three compounds, along with an $\mathrm{N}$-terminal octapeptide derived from verectin (a biologically active $14 \mathrm{kDa}$ glycoprotein present in Aloe vera), were tested for their relative antitumor efficacy in vivo. It was found that the active compounds exhibited significant prolongation of the life span of tumor-transplanted animals in the following order: barbaloin (aloin) > octapeptide > aloesin > aloe-emodin. Aloe vera active compounds exhibited significant inhibition on the Ehrlich ascite carcinoma cell (EACC) number when compared to the positive control group, in the following order: barbaloin > aloe-emodin > octapeptide > aloesin. Moreover, in the trypan blue cell viability assay, active compounds showed a significant concentration-dependent cytotoxicity against acute myeloid leukemia (AML) and acute lymphocytes leukemia (ALL) cancerous cells. Furthermore, aloe-emodin was found to be active against two human colon cancer cell lines, DLD-1 and HT2 [48].

The influence of Aloe vera leaves homogenized with honey and ethanol on tumor growth and the apoptosis process were verified by assessing tumor size, cell proliferation rate measured by the Ki67-labeling index (LI), and Bax/Bcl2 expression, after Walker 256 carcinoma was implanted in Wistar rats [49]. The effect against tumor growth was observed through a decrease in relative weight (\%) and the Ki67-LI labeling index in tumors from the tumor bearing group (WA group), compared with those from the control group (CW group). The Bax/Bcl2 ratio increased in tumors from the WA group at all tested time points. It was suggested that Aloe vera may reduce tumor mass and metastasis rates, while the honey inhibits tumor growth.

The in vivo and in vitro antitumor effects of Xianlukangai capsules, containing the polysaccharides from Opuntia Milpa Alta and Aloe vera L., were investigated [50]. Xianlukangai capsules inhibited the growth of cancer cells of S180A mice, and prolonged the survival time of H22 mice. Xianlukangai capsules also had 
strong cytotoxic effects on HepG2 cells, and increased its internal $\mathrm{Ca}^{2+}$. Xianlukangai capsules were found to decrease the activity of $\mathrm{Ca}^{2+}, \mathrm{Mg}^{2+}$-ATPase. The study indicated that Xianlukangai capsules had antitumor effects both in vivo and in vitro, and suggests a mechanism of increasing the internal $\mathrm{Ca}^{2+}$ in HepG2 cell through decreasing the activity of $\mathrm{Ca}^{2+}, \mathrm{Mg}^{2+}$-ATPase of the HepG2 cell membrane to induce apoptosis of the tumor.

Aloe vera extracts are widely used in skin care products. A study examined the effects of synthetic solar light on the skin of hairless mice that had been treated with creams containing various Aloe vera extracts. The results indicated that Aloe gel or aloeemodin had a weak enhancing effect on the photocarcinogenic activity of simulated solar light in female, but not male hairless mice. Aloe's whole leaf extract and decolorized leaf extract had a weak enhancing effect on the photocarcinogenic activity of simulated solar light in both male and female hairless mice [51].

\section{Clinical studies}

Clinical investigations showed the efficacy of extracts derived from Aloe arborescens in the palliative therapy of patients with untreatable metastatic cancer, either to improve their quality of life, or to prolong the survival time [52]. It demonstrated the efficacy of Aloe arborescens in association with cancer therapies in which the therapeutic effect of chemotherapy alone is generally low.

A patent describes a gel composition which includes at least $40 \%$ $(\mathrm{w} / \mathrm{w})$ Aloe barbadensis (Aloe vera) extract in treating breast tissues after radiation treatment for breast cancer [53].

A patent presents an anticancer preparation for suppressing cancerous tissue growth and metastases spreading. The extract contains Viskum allum-imula, Aloe vera, propolis, and placenta (Placeutofil). This anticancer preparation has been claimed to stop the fabric division of the cancer cells and strengthen the organism's defensive system [54].

A patent describes a method for treating neoplasia by forming a mixture between a portion of a nonhuman protein having human C3 convertase activity and an inhibitor of that activity, and administering a therapeutically effective amount of that mixture into a patient. The $\mathrm{C} 3$ convertase can be derived from plants, such as Aloe vera, Aloe arborescens, Aloe barbadensis, or Aloe saponaria [55].

The effects of methanol extract of Aloe vera were tested on anticancer drugs (cisplatin, mitomycin C, 5-FU)-induced growth inhibition of P388, L1210, HCT-15, and SK-HepG-1 as cancer cell lines, and mouse splenocytes as a normal cell line by the MIT assay, respectively. The effects of Aloe extract and mitomycin C on the mitogen (Con A and LPS)-induced splenocyte proliferation were also explored. In the Walker 256 carcinoma implant in Wistar rats, Aloe extract showed dose-dependent selective cytotoxicity against the cancer cell lines. In contrast, Aloe extract increased the growth and proliferation of the normal mouse splenocytes. The combination of Aloe extract with anticancer drugs showed an additive effect in the cytotoxicity against cancer cell lines. That combination clearly reduced the anticancer drug-induced toxicity against the normal mouse splenocytes [56].

\section{Conclusion}

$\nabla$

The potential ability of polyphenol combinations to prevent cancer progression is far from being completely understood, as it appears extremely unlikely that any one substance is responsible for all of the associations seen between the secondary metabolites contained in plants. This conclusion stems from the great va- riety of dietary phenolics and the many types of potential mechanisms reported [57]. It has been straightly pointed out that combinations of phytochemicals in fruits and vegetables are crucial for their anticancer activities [58].

The above may equally be projected on the biological effects of single components isolated from Aloe plants. As shown in this review article, the anticancer attributes of various components contained in plants of the Aloe genus have been extensively researched: aloin, with its anti-metastatic potential and minimal undesirable side effects for treating human uterine carcinoma [16]; aloe-emodin as source of novel chemotherapeutic drugs for the treatment of human gastric carcinoma [36]; or the anticancer attributes of the polysaccharides (mannan and acemannan) isolated from the gel of Aloe plants [10]. However, the combined anticancer mechanisms and effects of the various ingredients contained in the Aloe leaf have still to be explored. To this should be added the fact that only a small part of the plants belonging to the Aloe genus have thoroughly been investigated for their anticancer potential. However, the vast knowledge already gathered points to the great natural cancer preventive and therapeutic potential hidden in them.

\section{Conflict of Interest}

\section{$\nabla$}

The authors have no conflicts of interest.

\section{References}

1 Reynolds T, Dweek A. Aloe vera leaf gel: a review update. J Ethnopharmacol 1999; 68: 3-37

2 Gutterman $Y$, Chauser-Volfson E. Secondary phenol metabolites (SPhMs), distribution and content of some Aloe species, originated from arid zones of South Africa: a review. Am J Food Technol 2007; 2: 555-569

3 Van Wyk BE, Van Oudtshoom B, Gericke N. Medicinal plants of South Africa. Pretoria: Briza Publications; 1997

4 Zhang L, Tizard IR. Activation of a mouse macrophage cell line by acemannan: the major carbohydrate fraction from Aloe vera gel. Immunopharmacology 1996; 35: 119-128

5 Grindlay D, Reynolds $T$. The Aloe vera phenomenon: a review of the properties and modern uses of the leaf parenchyma gel. J Ethnopharmacol 1986; 16: 117-151

6 Tizard IR, Ramamoorthy L. Aloes and the immune system, Vol. 38. In: Reynolds T, editor. Aloes: the genus Aloe. Boca Raton: Medicinal Aromatic Plants - Industrial Profiles; 2004: 311-332

$7 \mathrm{Kim}$ HS, Lee BM. Inhibition of benzo[a]pyrene-DNA adduct formation by Aloe barbadensis Miller. Carcinogenesis 1997; 18: 771-776

8 Im S-A, Oh S-T, Song S, Kim M-R, Kim D-S, Woo S-S, Jo TH, Park YI, Lee C-K. Identification of optimal molecular size of modified Aloe polysaccharides with maximum immunomodulatory activity. Int Immunopharmacol 2005; 5: 271-279

9 Sampedro MC, Artola RL, Murature M, Murature D, Ditamo Y, Roth GA, Kivatinitz S. Mannan from Aloe saponaria inhibits tumoral cell activation and proliferation. Int Immunopharmacol 2004; 4: 411-418

10 Peng SY, Norman J, Curtin G, Corrier D, McDaniel HR, Busbee D. Decreased mortality of Norman murine sarcoma in mice treated with the immunomodulator, Acemannan. Mol Biother 1991; 3: 79-87

11 Qiu L, Tang S, Liu P. Pharmacological use of aloe polysaccharide in resisting liver cancer cell proliferation. Faming Zhuanli Shenqing 2010: CN 101879180 A 20101110

12 Liu C, Leung MYK, Koon JCM, Zhu LF, Hu YZ, Yu B, Fung KP. Macrophage activation by polysaccharide biological response modifier isolated from Aloe vera L. var. chinensis (Haw) Berg. Int Immunopharmacol 2006; 6: 1634-1641

13 Wang Z, Wang Y, Huang Z, Zhong S, Wu Y, Yu L. Study on antitumor effect and mechanism of Aloe polysaccharides. Zhong Yao Cai 2001; 24: 350-353 
14 Harris C, Pierce K, King G, Yates KM, Hall J, Tizard I. Efficacy of acemannan in treatment of canine and feline spontaneous neoplasms. Mol Biother 1991; 3: 207-213

15 Kumar S, Matharasi DP, Gopi S, Sivakumar S, Narasimhan S. Synthesis of cytotoxic and antioxidant Schiff's base analogs of aloin. J Asian Nat Prod Res 2010; 12: 360-370

16 Niciforovic A, Adzic M, Zabric B, Radojcic MB. Adjuvant antiproliferative and cytotoxic effect of aloin in irradiated HeLaS3 cells. Biophys Chem 2007; 81: 1463-1466

17 Niciforovic A, Adzic M, Spasic SD, Radojcic MB. Antitumor effects of a natural anthracycline analog (aloin) involve altered activity of antioxidant enzymes in HeLaS3 cells. Cancer Biol Ther 2007; 6: 1200-1205

18 Esmat AY, Tomasetto C, Rio M-C. Cytotoxicity of a natural anthraquinone (aloin) against human breast cancer cell lines with and without ErbB-2-topoisomerase II $\alpha$ coamplification. Cancer Biol Ther 2006; 5: 97-103

19 Krumbiegel G, Schulz HU. Rhein and aloe-emodin kinetics from senna laxatives in man. Pharmacology 1993: 47: 120-124

20 Agarwal SK, Singh SS, Verma S, Kumar S. Antifungal activity of anthraquinone derivatives from Rheum emodi. J Ethnopharmacol 2000; 72: 43-46

21 Hatano T, Uebayashi $H$, Ito H, Shiota S, Tsuchiya T, Yoshida T. Phenolic constituents of Cassia seeds and antibacterial effect of some naphthalenes and anhraquinones on methicillin-resistant Staphylococcus aureus. Chem Pharm Bull 1999; 47: 1121-1127

22 Arosio B, Gagliano N, Fusaro LM, Parmeggiani L, Tagliabue J, Galetti P, De Castri D, Moscheni C, Annoni G. Aloe-emodin quinone pretreatment reduces acute liver injury induced by carbon tetrachloride. Pharmacol Toxicol 2000; 87: 229-233

23 Andersen DO, Weber ND, Wood SG, Hughes BG, Murray BK, North JA. In vitro virucidal activity of selected anthraquinones and anthraquinone derivatives. Antiviral Res 1991; 16: 185-196

24 Acevedo-Duncan M, Russell C, Patel S, Patel R. Aloe-emodin modulates PKC isozymes, inhibits proliferation, and induces apoptosis in U373MG glioma cells. Int Immunopharmacol 2004; 4: 1775-1784

25 Grimaudo S, Tolomeo M, Gancitano RA, D'Alessandro N, Aiello E. Effects of highly purified anthraquinoid compounds form Aloe vera on sensitive and multidrug-resistant leukemia cells. Oncol Rep 1997; 4: 341343

26 Lin KY, Uen YH. Aloe-emodin, an anthraquinone, in vitro inhibits proliferation and induces apoptosis in human colon carcinoma cells. Oncol Lett 2010; 1: 541-547

27 Harhaji L, Mijatovic S, Maksimovic-Ivanic D, Popadic D, Isakovic A, Todorovic-Markovic B, Trajkovic V. Aloe-emodin inhibits the cytotoxic action of tumor necrosis factor. Eur J Pharmacol 2007; 568: 248-259

28 Guo J, Xiao B, Liu Q Gong Z, Le Y. Suppression of C-myc expression associates with anti-proliferation of aloe-emodin on gastric cancer cells. Cancer Invest 2008; 26: 369-374

29 Lin J-G, Chen G-W, Li T-M, Chouh S-T, Tan T-W, Chung J-G. Aloe-emodin induces apoptosis in T24 human bladder cancer cells through the p 53 dependent apoptotic pathway. J Urol 2006; 175: 343-347

30 Mijatovic S, Maksimovic-Ivanic D, Radovic J, Miljkovic DJ, Harhaji LJ, Vuckovic O, Stosic-Grujicic S, Stojkovic MM, Trajkovic V. Anti-glioma action of aloe-emodin: the role of ERK inhibition. Cell Mol Life Sci 2005; 62: 589-598

31 Lee H-Z, Hsu S-L, Liu M-C, Wu C-H. Effects and mechanisms of aloeemodin on cell death in human lung squamous cell carcinoma. Eur J Pharmacol 2001; 431: 287-295

32 Kuo $P$-L, Lin T-C, Lin C-C. The antiproliferative activity of aloe-emodin is through p53-dependent and p21-dependent apoptotic pathways in human hepatoma cell lines. Life Sci 2002; 71: 1879-1892

33 Yeh FT, Wu CH, Lee HZ. Signaling pathway for aloe-emodin-induced apoptosis in human H460 lung nonsmall carcinoma cell. Int J Cancer 2003; 106: 26-33

34 Wasserman L, Avigad S, Beery E, NordenbergJ, Fenig E. The effect of aloeemodin on the proliferation of a new merkel carcinoma cell line. Am J Dermatopathol 2002; 24: 17-22

35 Chiu TH, Lai WW, Hsia TC, Yang JS, Lai TY, Wu PP, Ma CY, Yeh CC, Ho CC, Lu HF, Wood WG, Chung JG. Aloe-emodin induces cell death through Sphase arrest and caspase-dependent pathways in human tongue squamous cancer SCC-4 cells. Anticancer Res 2009; 29: 4503-4511
36 Chen SH, Lin KY, Chang CC, Fang CL, Lin CP. Aloe-emodin-induced apoptosis in human gastric carcinoma cells. Food Chem Toxicol 2007; 45: 2296-2303

37 Pecere T, Gazzola MV, Mucignat C, Parolin C, Dalla VF, Cavaggioni A, Basso G, Diaspro A, Salvato B, Carli M, Palu G. Aloe-emodin is a new type of anticancer agent with selective activity against neuroectodermal tumors. Cancer Res 2000; 60: 2800-2804

38 Yoshimoto R, Kondoh N, Isawa M, Hamuro J. Plant lectin, ATF1011, on the tumor cell surface augments tumor-specific immunity through activation of T cells specific for the lectin. Cancer Immunol Immunother 1987; 25: 25-30

39 Kenichi I. Aloctin A, an active substance of Aloe arborescens Miller as an immunomodulator. Phytother Res 1993; 7: S20-S22

40 Imanishi K, Ishiguro T, Saito H, Suzuki I. Pharmacological studies on a plant lectin, aloctin A. I. Growth inhibition of mouse methylcholanthrene-induced fibrosarcoma (Meth A) in ascites form by Aloctin A. Experientia 1981; 37: 1186-1187

$41 \mathrm{Kim}$ I, Kwon H. Induction of apoptosis by Aloe vera extract in human hepatocellular carcinoma HepG2 cells. J Toxicol Publ Health 2006; 22: 329-332

42 Van Wyk BE, Smith G. Guide to the Aloes of South Africa. Pretoria: Briza Publications; 1996

43 Yagi A, Makino K, Nishioka I, Kuchino Y. Aloe mannan, polysaccharide, from Aloe arborescens var. natalensis. Planta Med 1977; 31: 17-20

44 Furukawa F, Nishikawa A, Chihara T, Shimpo K, Верpu H, Kuzuya H, Lee IS, Hirose M. Chemopreventive effects of Aloe arborescens on N-nitrosobis(2-oxopropyl)amine-induced pancreatic carcinogenesis in hamsters. Cancer Lett 2002; 178: 117-122

45 Okada K. Studies on in vitro and in vivo effects of aloe extract on hepatocarcinogenesis. Wakayama Igaku 1997; 48: 85-95

46 Su Y, Guo X, Huang X, Jiang B, Bai Y, Bai H. Experimental studies on antitumor action of Aloe. Zhongguo Yaoshi 2006; 9: 486-488

47 Jeong HY, Kim JH, Hwang SJ, Rhee DK. Anticancer effects of aloe on sarcoma 180 in ICR mouse and on human cancer cell lines. Yakhak Hoechi 1994; 38: 311-321

48 El-Shemy HA, Aboul-Soud, MAM, Nassr-Allah AA, Aboul-Enein KM, Kabash $A$, Yagi A. Antitumor properties and modulation of antioxidant enzymes activity by Aloe vera leaf active principles isolated via supercritical carbon dioxide extraction. Curr Med Chem 2010; 17: 129-138

49 Tomasin R, Cintra G-M, Maria C. Oral administration of Aloe vera and honey reduces Walker tumor growth by decreasing cell proliferation and increasing apoptosis in tumor tissue. Phytother Res 2011; 25: 619-623

50 Gao S, Li W, Zhang Y, Wang S, Ji Y. Antitumor function of Xianlukangai capsules and its effects on [Ca2+]i of human liver cancer cell line HepG2. Zhongcaoyao 2005; 36: 1675-1678

51 Kerkvliet N, editor. Photococarcinogenesis study of Aloe vera in SKH-1 mice (Simulated solar light and topical application study). National Toxicology Program Technical Report Series 2010; 553: 1-205

52 Lissoni P, Rovelli F, Brivio F, Zago R, Colciago M, Messina G, Mora A, Porro $G$. A randomized study of chemotherapy versus biochemotherapy with chemotherapy plus Aloe arborescens in patients with metastatic cancer. In Vivo 2009; 23: 171-175

53 Loeschnigg I. Sambucus- and Aloe-containing topical composition for treating radiation-damaged dry and non-elastic skin. EP Patent 2181701 A1 20100505; 2010

54 Gorgiev I. Anticancer composition/composition for stopping the fabric division of the cancer cells and strengthening the defensive system of the organism. WO Patent 9938519 A1; 1999

55 Ferretti F, Ferretti A. Compositions and methods for diagnosis and treatment of cancer including snake venom C3 convertase and its inhibitor from human serum. US Patent 20080057052 A1 20080306; 2008

56 Pyo M-Y, Youn J-H. Effects of Aloe vera on the cytotoxicity of anticance drugs in vitro. YakhakHoechi 1999; 43: 104-110

57 Birt DF, Hendrich S, Wang WQ. Dietary agents in cancer prevention: flavonoids and isoflavonoids. Pharmacol Ther 2001; 90: 157-177

58 Sun J, Chu YF, Wu XZ, Liu RH. Antioxidant and antiproliferative activities of common fruits. J Agric Food Chem 2002; 50: 7449-7454 